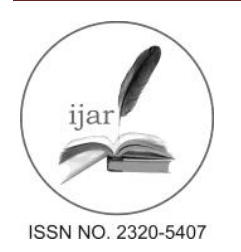

Journal homepage:http://www.journalijar.com

Journal DOI:10.21474/IJAR01

INTERNATIONAL JOURNAL

OF ADVANCED RESEARCH

RESEARCH ARTICLE

\title{
GEOCHEMISTRY OF TRIASSIC SANDSTONES (HIGH ATLAS OF MARRAKECH, MOROCCO): IMPLICATIONS FOR PROVENANCE, WEATHERING, AND TECTONIC SETTING.
}

\section{*O. AitMalek ${ }^{1}$, H. El Hadi ${ }^{1}$, H. El Haibi ${ }^{1}$, S. Fakhi' ${ }^{2}$ A. Ayach ${ }^{2}$, Z. Faiz $^{2}$, M. Benmansour ${ }^{3}$, A. Bouih ${ }^{3}$, S. El Aouidi $^{3}$ and A. Reddad ${ }^{4}$.}

1. Hassan II University of Casablanca, Applied Geology, Environment and Geomatics Laboratory / Faculty of Sciences Ben M'Sik CASABLANCA - Morocco.

2. Hassan II University of Casablanca, Engineering and Materials Laboratory

(LIMAT).ThermostructuralMaterials, Polymers and Radiochemistry Team(TMPR).

3. National Center for Nuclear Energy Sciences and Techniques.

4. Faculty of Science and Technology Marrakech, Geosciences and Environment Laboratory.

\section{Manuscript Info Abstract}

\section{Manuscript History:}

Received: 28 April 2016

Final Accepted: 11 May 2016

Published Online: June 2016

Key words:

Geochemistry,provenance, weathering,tectonic setting, sandstones,IGHERMANE, AITKEJOU.

*Corresponding Author

AitMalek.O.
The geochemical composition of fifteen fresh Triassic sandstone samples from two localities (Oukaimeden and Ourika Valley, Morocco) was carried out, in order to assess their provenance, weathering and tectonic setting. These sandstones are classified as litharenites and wackestones. The CIA (Chemical Index of Alteration; mean value $\mathrm{GK}=57.6$ and $\mathrm{GI}=71.77$ ) values and $\mathrm{Al}_{2} \mathrm{O}_{3}-\mathrm{CaO}+\mathrm{Na}_{2} \mathrm{O}-\mathrm{K}_{2} \mathrm{O}$ suggest that the source materials for these sandstones must have been subjected to low and moderate degree of weathering and reworking. Sandstones from studied areas had a high $\mathrm{SiO} 2$ content in the range of $62-82 \%$ due to their mineralogical maturation. However, the negative correlation between $\mathrm{SiO} 2$ content and the other major elements proposes another contribution of silica. AIT KEJOU sandstones show the presence of a small amount of clay minerals than IGHERMANE sandstones. The Upper Continental Crust (UCC) and North American Shales (NASC) normalization showed depletion in light rare earth elements (LREE) and enrichment in HREE. The negative europium $\left(\mathrm{Eu} / \mathrm{Eu}^{*}\right)$ anomaly support a felsic rocks provenance of the studied sandstones. The cerium $(\mathrm{Ce} / \mathrm{Ce} *)$ anomaly indicated an oxidizing depositional environment. The depletion in LREE in relation to the HREE and low $\mathrm{La} / \mathrm{Lu}$ ratio values suggest that the sandstones are as a result of fluvial/river channel system with a slight sea contribution. According to the provenance discrimination diagram, the sandstones were derived from the adjacent Cambrian basement units of Tifnout granitic massif, associated andesites and the granodiorites of the Precambrian basement units of Central High Atlas, located to the south of the studied areas. Discrimination diagrams suggested a passive margin tectonic setting for AIT KEJOU sandstones and an active continental margin tectonic setting for the IGHERMANE sandstones.

Copy Right, IJAR, 2016. All rights reserved.

\section{Introduction:-}

The Triassic formation of Marrakech High Atlas including structural evolution (Petit and Beauchamp, 1986; Manspeizer, 2015), sedimentology, the architectural style and a detailed stratigraphy of their specific formation (Benaouiss et al., 1996; Kayser, 2005; Fabuel-Perez et al., 2010) have been studied by many authors. These outcrops provided in the valley of Ourika-Oukaimeden have an excellent exposures to investigate the respective roles played by the tectonic and climate on the filing of continental sediments (Baudon et al., 2009). 
The geochemical composition of the sedimentary rocks is controlled by several parameters. The study of this composition reveals very important information as provenance, weathering and tectonic setting (Bhatia, 1983). The meaning of the geochemical composition of these rocks have been studied by various authors like Schwab (1975); McLennan and al (1983); Taylor and McLennan (1985); Wronkiewicz, and Condie (1987); Roser and Korsch (1988); Condie and al 1991; McLennan and al (1993); Condie (1993); cullers (1994); Nesbitt and al (1997); cullers (2000); Yan and al (2007). In particular, the use of major and trace elements, supposed immobile to be transported in the load of particles (Taylor and McLennan, 1985; Cullers, 2000; Roser and Korsch, 1988). Currently, no geochemical study has been made on sandstones of this region. However, the contribution of the geochemistry of these Triassic sandstones has a benefit in the clarification of geodynamic context.

The aim of the study is to determine the variation of the levels of the major and rare earth elements in Oukaimeden sandstones, their provenance, weathering and tectonic setting. So, we have achieved a geochemical study of those sandstones based on 15 samples taken in two locations: AIT KEJOU (GK) and IGHERMANE (GI) (Fig. 1).

\section{Geographical and geological contexts:-}

The study area is located in the High Atlas of Morocco, $40 \mathrm{~km}$ south Marrakesh (Figure 1). The High Atlas is a mountain range oriented ENE consisting mainly of Mesozoic rocks, and is found between Precambrian and Paleozoic of the Anti-Atlas to the south and the ancient massif to the East. The Permo-Triassic succession of the central High Atlas basin of Morocco shows exceptional exhibition in Ourika-valley, dominated by fluvial sediments deposited in a continental Rift basin (Fabuel-Perez et al., 2010). These rift basins formed in response to extensional tectonics associated with the break-up of Pangea, attributed to the opening of the Atlantic Ocean and Neo-Tethys Sea (Houten, 1977; Petit and Beauchamp, 1986). These formations have been divided into six formations, based on their lithology and the identification of their major discontinuities (Mattis, 1977; Biron and Courtinat, 1982; Benaouiss et al., 1996)(Fig 2A).

Two formations have been the subject of this study:1) The Ramutcho Siltstone Formation (Mattis, 1977)(F4) ,200 m thick, begins with coarse levels to small pebbles, and continues with mainly silty sediment except two sandstone levels (Biron, 1982). 2) The Oukaimeden Sandstone Formation (Mattis, 1977)(F5) materialized by thick sandstone unit (Biron, 1982), and overlies F4 with a sharp contact in the north and a more gradational contact to the south (Fabuel-Perez et al., 2010).

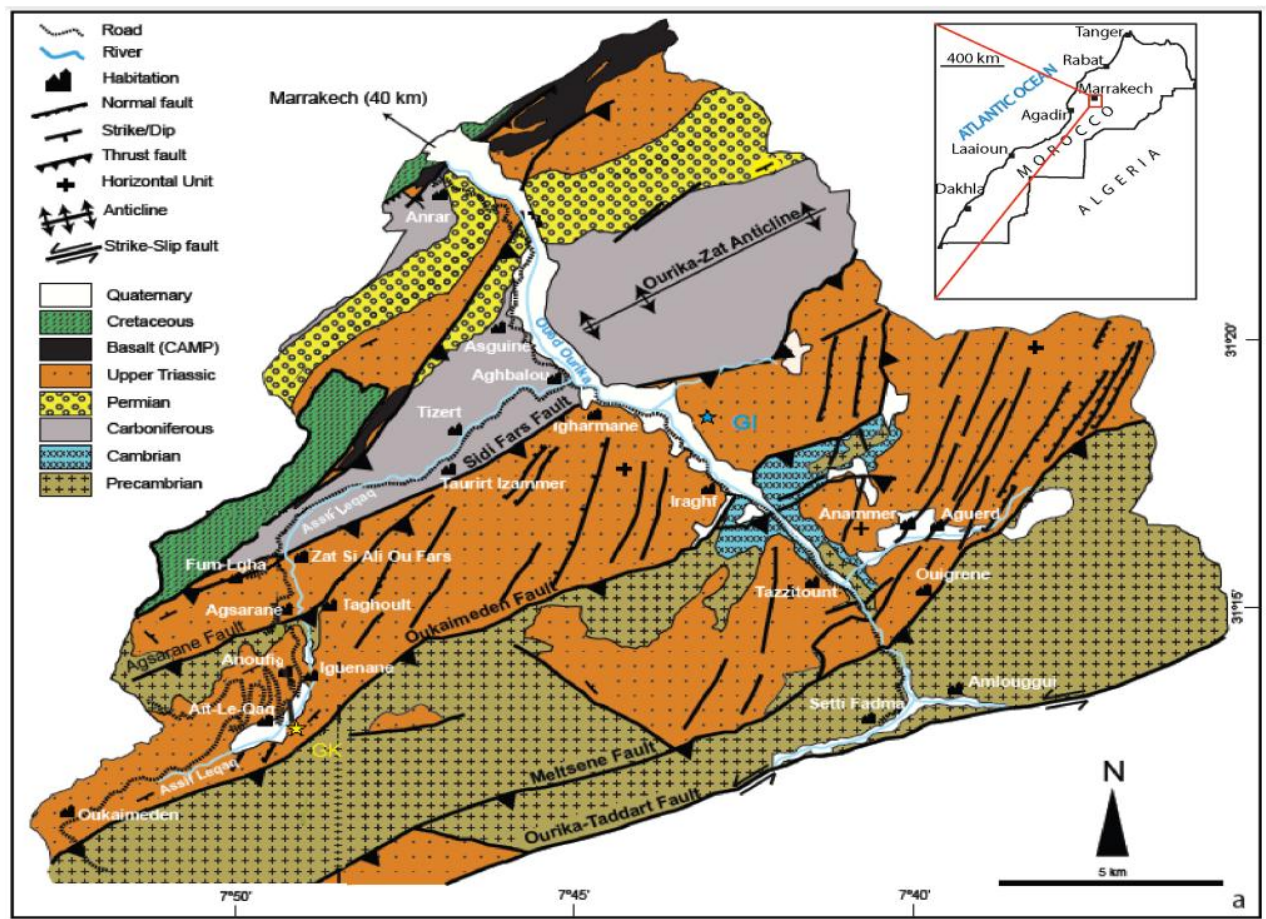

Figure 1 : Studied area location in thegeological map of the central High Atlas basin (Taj-EddinePignone, 2005, modified); GK: AIT Kejou, GI: Ighermane. 


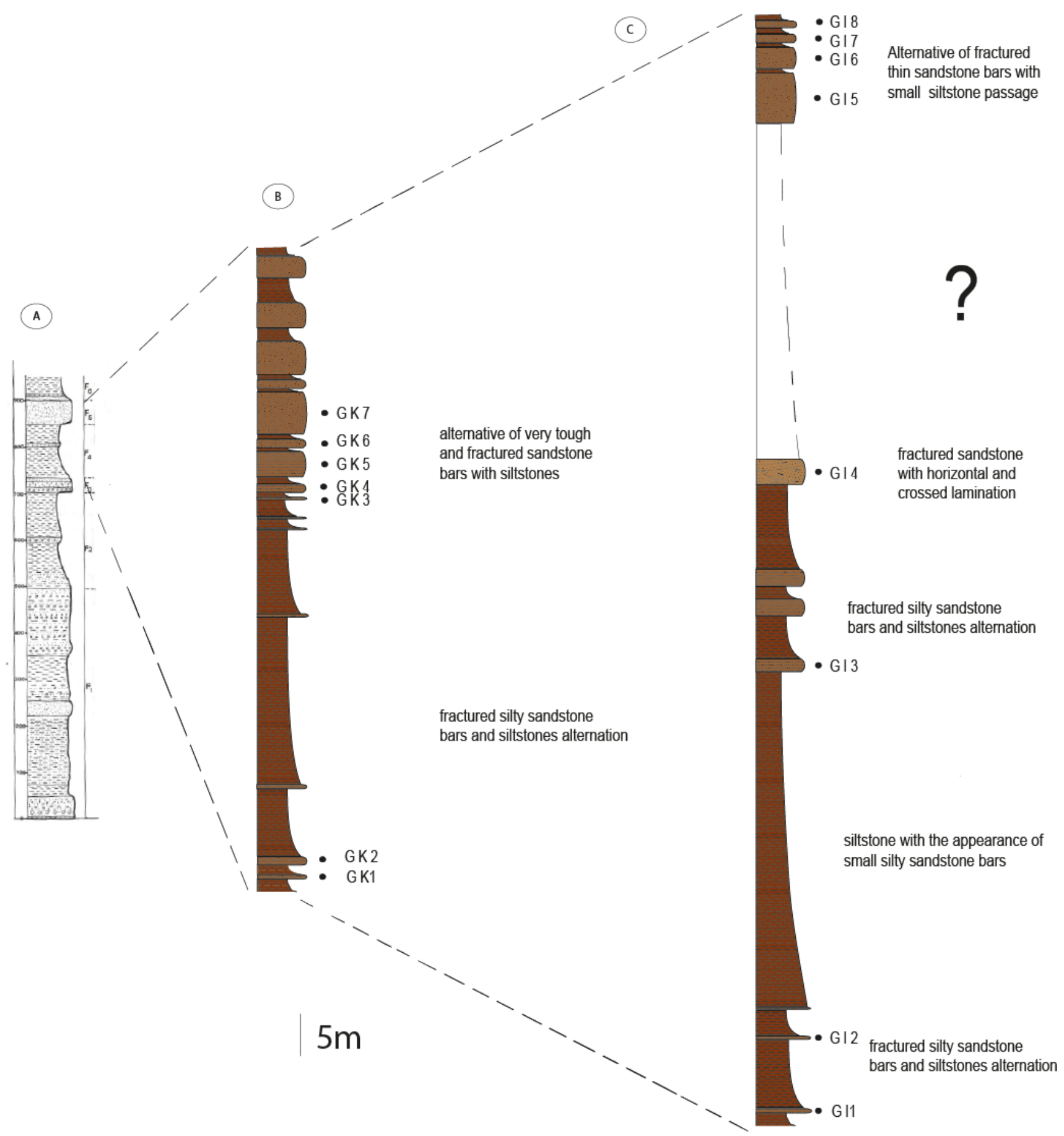

Figure 2 : Stratigraphic columns of the study areas. A: After Biron 1982; B: AIT KEJOU (GK) column, this work; C: IGHERMANE (GI) column, this work.

\section{Material and Methods:-}

Seven representative samples were collected in AIT KEJOU region (Fig. 1 and 2B) and eight in Ighermane (Fig. 1 and 2C). These samples were crushing and grinding in the Geology laboratory of Ben M'SIK Sciences Faculty, Hassan II University of Casablanca. Chemical analysis were conducted in National Center of Scientific and Technical Research (CNRST) of Rabat. The composition of major elements was determined by X-ray fluorescence spectrometry technique and rare earth elements by ICP AES technique (Table1). 


\section{Result and Discussion:- \\ Major elements:-}

The sandstones from the two studied areas reported an enrichment of $\mathrm{SiO}_{2}$ content (62 to $\left.82 \%\right)$, $\mathrm{TiO}_{2}$, with an average of $0.49 \%, \mathrm{Al}_{2} \mathrm{O}_{3}$ approximately $9.27 \%$ in AIT KEJOU sandstones , $12.07 \%$ in IGHERMANE , $\mathrm{Fe}_{2} \mathrm{O}_{3}+\mathrm{MgO}$ with an average of $3.31 \%$ in AIT KEJOU sandstones and $4.38 \%$ in those of IGHERMANE. The comparison between major elements content in studied areas shows enrichment in $\mathrm{Al}_{2} \mathrm{O}_{3}, \mathrm{Fe}_{2} \mathrm{O}_{3}, \mathrm{Na}_{2} \mathrm{O}$ and $\mathrm{MnO}_{2}$ in IGHERMANE sandstones and enrichment in $\mathrm{CaO}$ in AIT KEJOU sandstones. The high content of $\mathrm{Al}_{2} \mathrm{O}_{3}$ was due to the presence of clay minerals and micas subordinates (Banerjee, 2010). Most of AIT KEJOU sandstone samples show lower $\mathrm{Al}_{2} \mathrm{O}_{3}$ and high $\mathrm{CaO}$ content than that of IGHERMANE sandstones. These results indicate that sandstone from two areas can be derived from different provenance, as well give an idea on grain size fractionation during transport and sedimentation.

According to the chemical classification scheme of Herron (1988) (Fig. 3), IGHERMANE sandstones are classified as wacke to litharenite and litharenites for those of AIT KEJOU except for three samples that fall in the wacke and sublitharenite field.

Harker diagram was used to compare the abundances of the major element oxides with silica abundance (Fig. 4). $\mathrm{SiO}_{2}$ content showed a linear relationship with $\mathrm{Al}_{2} \mathrm{O}_{3}, \mathrm{Fe}_{2} \mathrm{O}_{3}, \mathrm{MgO}$, and $\mathrm{K}_{2} \mathrm{O}$ in both AIT KEJOU and IGHERMANE sandstones The negative correlation between $\mathrm{SiO}_{2}$ content with most of the elements is due to the significant amount of silica trapped in quartz, as reported by Osman (1996), as well Silica contribution. Generally, $\mathrm{SiO}_{2}$ abundance increase as $\mathrm{TiO}_{2}, \mathrm{Al}_{2} \mathrm{O}_{3}, \mathrm{Fe}_{2} \mathrm{O}_{3}, \mathrm{MnO}_{2}, \mathrm{MgO}, \mathrm{CaO}, \mathrm{K}_{2} \mathrm{O}$ and $\mathrm{Na}_{2} \mathrm{O}$ decrease in the studied areas; suggesting a cratonic and recycled sediments associated with passive margins provenances. The high rate of quartz is due to the mineralogical maturation (Bhatia, 1983). There was a dispersion in $\mathrm{CaO}, \mathrm{MgO}, \mathrm{Na}_{2} \mathrm{O}$ and $\mathrm{MnO}_{2}$ content in the samples analyzed and this can be related to their mobility. Therefore, $\mathrm{TiO}_{2}, \mathrm{Al}_{2} \mathrm{O}_{3}, \mathrm{Fe}_{2} \mathrm{O}_{3}$ and $\mathrm{K}_{2} \mathrm{O}$ content exhibit a regular correlation with $\mathrm{SiO}_{2}$. The titanium oxide in the IGHERMANE sandstones shows a low variation in function of the silica.

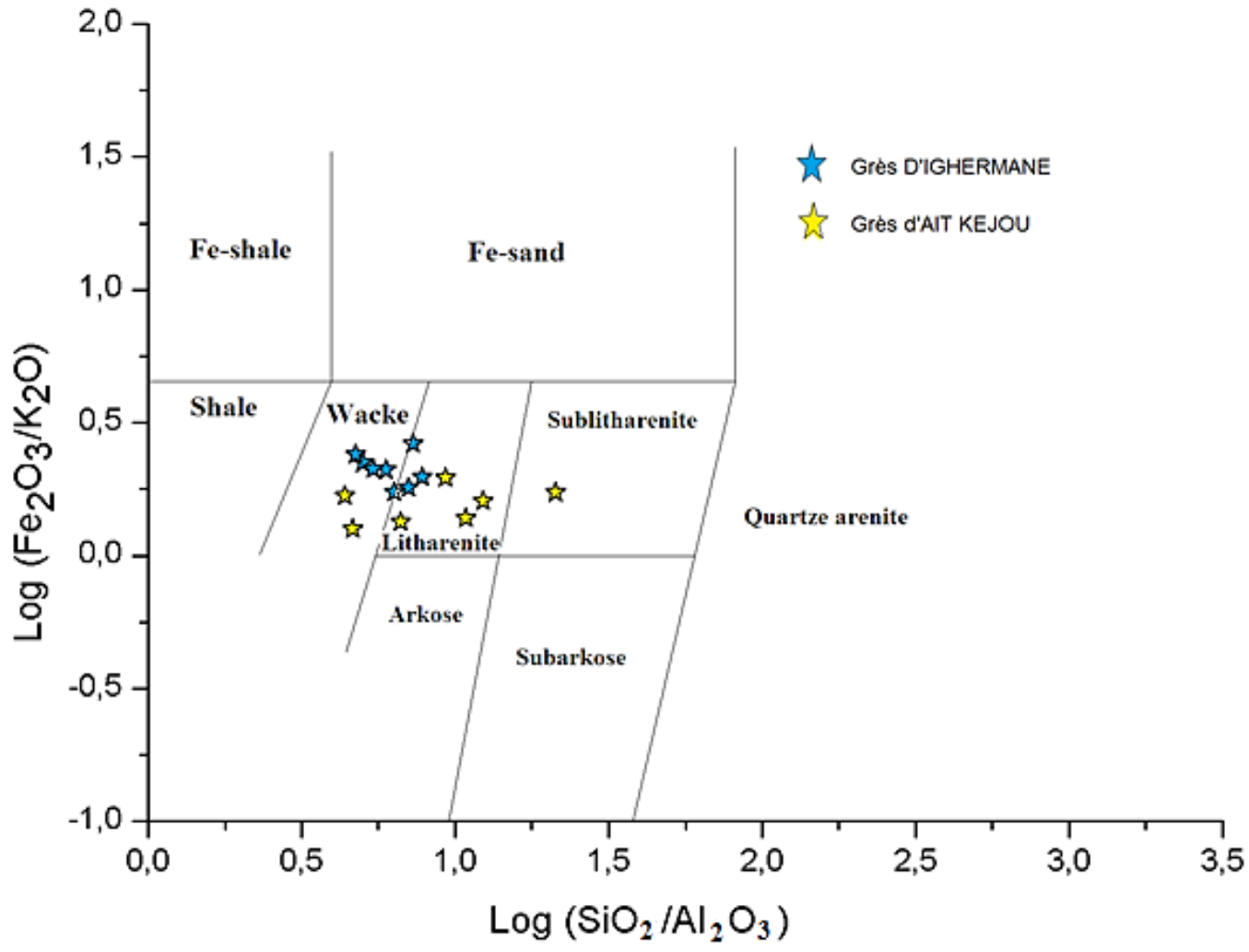

Figure 3 : Chemical classification scheme of Oukaimeden and Ourika-valley sandstones based on major elements (Herron 1988). 
Table 1 : Major and rare earth elements analyze ofstudied areas GK and GI.

Eu/Eu* $=\log [2 *$ EuNASC/(SmNASC+GdNASC) $]$; This/EC*=CeNASC/(0.5*(LaNASC+PrNASC)); $\sum$ REE (La-Lu); LREE (La-Gd); HREE (Dy-Lu); $\mathrm{n}=$ normalize by report to the NASC (Haskin and Haskin 1966)

\begin{tabular}{|c|c|c|c|c|c|c|c|c|c|c|c|c|c|c|c|}
\hline Sampls & GK1 & GK2 & GK3 & GK4 & GK5 & GK6 & Gk7 & GI1 & GI2 & GI3 & GI4 & GI5 & GI6 & GI7 & GI8 \\
\hline \multicolumn{16}{|l|}{ In wt $\%$} \\
\hline $\mathrm{SiO}_{2}$ & 76,5 & 62,6 & 73,2 & 63,4 & 82,8 & 74,6 & 88,5 & 70,4 & 69,2 & 79,8 & 80,2 & 68,3 & 72,5 & 73,5 & 73,4 \\
\hline $\mathrm{Al}_{2} \mathrm{O}_{3}$ & 7,06 & 13,5 & 11 & 14,5 & 6,71 & 8,01 & 4,16 & 11,8 & 13,8 & 10,2 & 11 & 14,4 & 13,4 & 11,6 & 10,4 \\
\hline $\mathrm{CaO}$ & 1,25 & 6,42 & 4,75 & 10,4 & 3,42 & 7,02 & 2,3 & 1,98 & 1,75 & 0,16 & 0,49 & 3,83 & 2,3 & 4 & 5,46 \\
\hline $\mathrm{Fe}_{2} \mathrm{O}_{3}$ & 1,51 & 2,87 & 2,25 & 3,67 & 1,46 & 2,53 & 1,03 & 2,58 & 3,41 & 2,04 & 2,29 & 3,31 & 2,53 & 2,27 & 2,25 \\
\hline $\mathrm{K}_{2} \mathrm{O}$ & 1,09 & 2,27 & 1,68 & 2,19 & 0,91 & 1,29 & 0,6 & 1,23 & 1,53 & 1,03 & 0,87 & 1,38 & 1,19 & 1,31 & 1,25 \\
\hline $\mathrm{MgO}$ & 0,81 & 1,65 & 1,36 & 1,86 & 0,77 & 0,88 & 0,51 & 2,1 & 2,38 & 0,98 & 1,48 & 2,72 & 2,05 & 1,56 & 1,14 \\
\hline $\mathrm{TiO}_{2}$ & 0,33 & 0,55 & 0,37 & 0,74 & 0,21 & 0,64 & 0,14 & 0,58 & 0,57 & 0,65 & 0,55 & 0,57 & 0,38 & 0,4 & 0,37 \\
\hline $\mathrm{Na}_{2} \mathrm{O}$ & 0,52 & 1,05 & 0,65 & 0,83 & 0,47 & 0,63 & 0,42 & 1,39 & 1,05 & 1,37 & 0,72 & 1,08 & 1,74 & 1,31 & 1,18 \\
\hline $\mathrm{MnO}_{2}$ & 0,09 & 0,18 & 0,14 & 0,19 & 0,06 & 0,19 & 0,25 & 0,72 & 0,59 & 0,03 & & 0,62 & 0,06 & 0,1 & 0,06 \\
\hline $\mathrm{P}_{2} \mathrm{O}_{5}$ & 0,09 & 0,24 & 0,11 & 0,18 & 0,09 & 0,15 & 0,1 & 0,06 & 0,08 & 0,07 & 0,11 & 0,16 & 0,13 & 0,12 & 0,15 \\
\hline CIA & 71,18 & 58,09 & 60,84 & 51,93 & 58,27 & 47,27 & 55,61 & 71,95 & 76,12 & 79,96 & 84,05 & 69,6 & 71,93 & 63,67 & 56,86 \\
\hline \multicolumn{16}{|l|}{ In $\mathrm{ppm}$} \\
\hline $\mathrm{La}$ & 22,76 & & 4,84 & & 2,93 & & 2,2 & 15,96 & & 2,04 & & 3,15 & & 2,23 & \\
\hline $\mathrm{Ce}$ & 16,26 & & 52,77 & & 34,64 & & 46,29 & 39,91 & & 59,29 & & 44,14 & & 28,95 & \\
\hline $\operatorname{Pr}$ & 3,25 & & 4,4 & & 2,66 & & 2,2 & 3,33 & & 2,27 & & 3,15 & & 2,23 & \\
\hline $\mathrm{Nd}$ & 28,29 & & 4,4 & & 2,66 & & 2,2 & 130,69 & & 2,27 & & 22,39 & & 2,23 & \\
\hline $\mathrm{Sm}$ & 0,3 & & 0,32 & & 0,23 & & 0,15 & 0,34 & & 0,36 & & 0,35 & & 0,04 & \\
\hline $\mathrm{Eu}$ & 0,74 & & 0,84 & & 0,39 & & 0,19 & 0,74 & & 0,71 & & 0,7 & & 0,41 & \\
\hline $\mathrm{Gd}$ & 5,53 & & 14,95 & & 23,72 & & 8,38 & 18,62 & & 13,63 & & 27,12 & & 1,78 & \\
\hline Dy & 31,86 & & 46,61 & & 2,4 & & 21,6 & 108,08 & & 21,58 & & 80,72 & & 7,13 & \\
\hline Ho & 12,68 & & 27,7 & & 9,06 & & 7,05 & 18,29 & & 5,22 & & 16,4 & & 2,67 & \\
\hline $\mathrm{Er}$ & 3,25 & & 5,28 & & 2,66 & & 2,2 & 3,33 & & 2,27 & & 3,15 & & 2,23 & \\
\hline $\mathrm{Tm}$ & 0,33 & & 0,47 & & 0,26 & & 0,16 & 0,37 & & 0,45 & & 0,44 & & 0,42 & \\
\hline $\mathrm{Yb}$ & 3,25 & & 4,4 & & 2,66 & & 2,2 & 3,33 & & 2,27 & & 3,15 & & 2,23 & \\
\hline $\mathrm{Lu}$ & 3,25 & & 4,4 & & 2,66 & & 2,2 & 3,33 & & 2,27 & & 3,15 & & 2,23 & \\
\hline$\sum \mathrm{REE}$ & 131,76 & & 171,38 & & 86,92 & & 97,02 & 346,32 & & 114,63 & & 208,01 & & 54,77 & \\
\hline LREE/HREE & 1,41 & & 0,93 & & 3,41 & & 1,74 & 1,53 & & 2,37 & & 0,94 & & 2,24 & \\
\hline $\mathrm{Ce} / \mathrm{Ce}^{*}$ & 0,41 & & 2,13 & & 2,31 & & 3,81 & 1,24 & & 4,82 & & 2,54 & & 2,35 & \\
\hline $\mathrm{Eu} / \mathrm{Eu}^{*}$ & 1,33 & & 0,92 & & 0,54 & & 0,87 & 0,75 & & 0,84 & & 0,54 & & 2,46 & \\
\hline $\mathrm{La} / \mathrm{Sc}$ & 2,92 & & 0,69 & & 1,1 & & 1,25 & 2,29 & & 0,36 & & 0,48 & & 0,56 & \\
\hline$(\mathrm{La} / \mathrm{Lu}) \mathrm{n}$ & 0,71 & & 0,11 & & 0,11 & & 0,10 & 0,49 & & 0,09 & & 0,10 & & 0,10 & \\
\hline
\end{tabular}



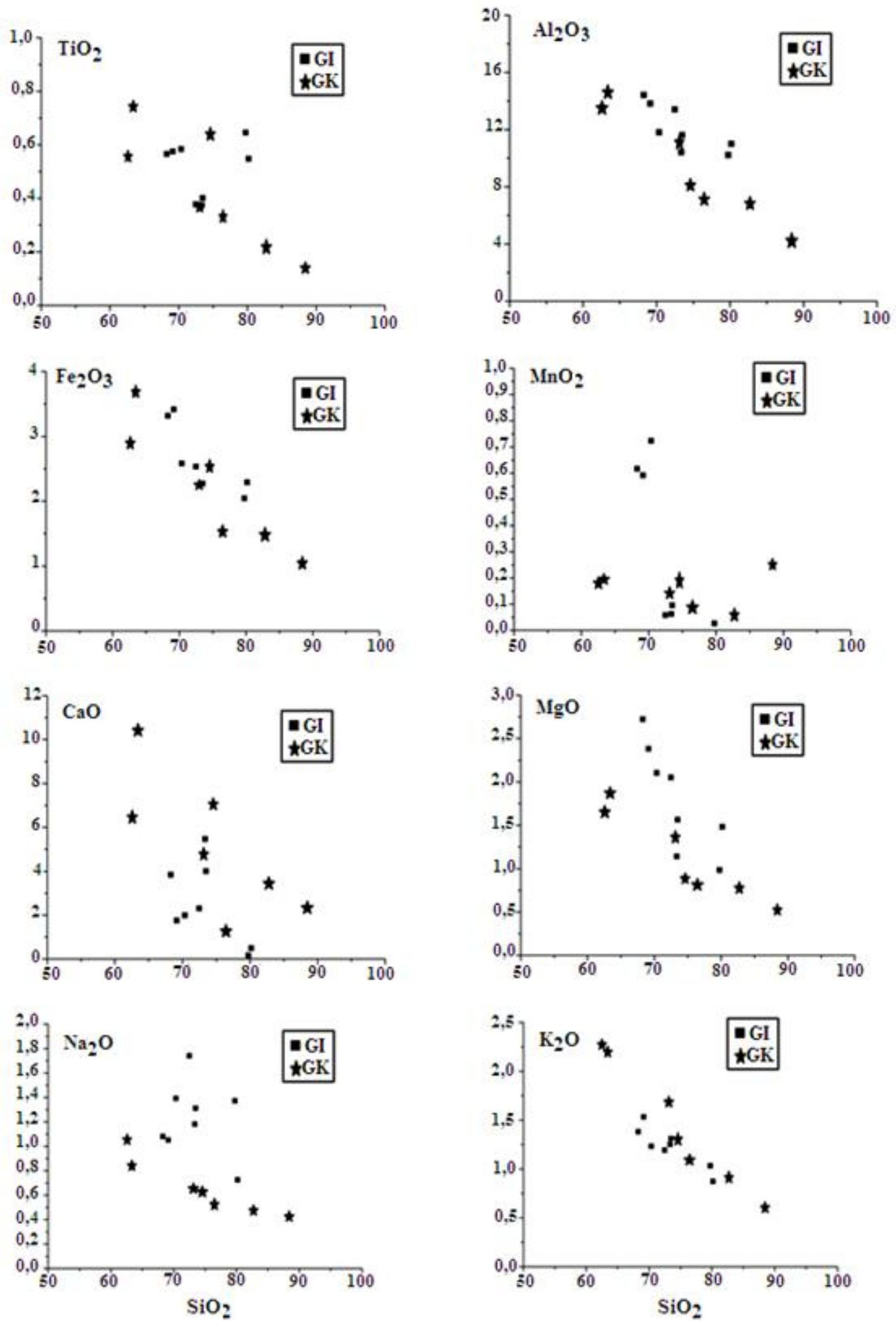

Figure 4 :Harker variation diagram for sandstones samples from two areas, AIT KEJOU (GK) \& IGHERMANE (GI). 


\section{Rare earth elements:-}

The rare earths elements are known to be strong resistance to the weathering conditions, which make them good indicators of sediments provenance and tectonic setting. In IGHERMANE sandstones, $\Sigma$ REE concentration vary widely from 54.77 to $346.31 \mathrm{ppm}$ (average $180.93 \mathrm{ppm}$ ), and from 86.92 to $171.38 \mathrm{ppm}$ (with an average of 121.77 ppm) in AIT KEJOU sandstones. All samples of the analyzed sandstones show less $\Sigma$ REE abundances compared to the upper continental crust (UCC) ( $\approx 143 \mathrm{ppm}$; Taylor and McLennan 1985), except for GI1, GI5 and GK3 samples (Table 1). The upper continental crust normalized REE distribution (Taylor and McLennan, 1985)shows depletion in light rare earth element (LREE) in relation to the heavy REE (HREE) except for Nd in GI1 sample (Fig. 5). The NASC normalized REE distribution (Haskin and Haskin, 1966) shows a similar trend of the UCC in both studied areas, with variables concentrations in $\mathrm{Nd}, \mathrm{Gd}, \mathrm{Tm}, \mathrm{Yb}$, and $\mathrm{Lu}$ (Fig. 5). The parallel appearances of the normalization patterns suggest that these sandstones have the same provenance. The negative europium (Eu/Eu*) anomaly support a felsic rocks provenance of the studied sandstones, except for GK1 and GK7. The cerium $\left(\mathrm{Ce} / \mathrm{Ce}^{*}\right)$ anomaly can be used as indicator of the depositional environment conditions (McDaniel et al., 1994), in our study, the cerium $\left(\mathrm{Ce} / \mathrm{Ce}^{*}\right)$ anomaly indicated an oxidizing depositional environment. The observed $\mathrm{Sm}$ anomaly is probably related to the samples preparation as indicated by Rousseau (2013).The depletion in light rare earth elements (LREE) in relation to the HREE and the low $\mathrm{La} / \mathrm{Lu}$ ratio values are similar to that of the rivers waters (Rousseau et al., 2013). These results suggest that sediments are products of fluvial/river channel system with a slight sea contribution, confirming the results of Biron (1982).
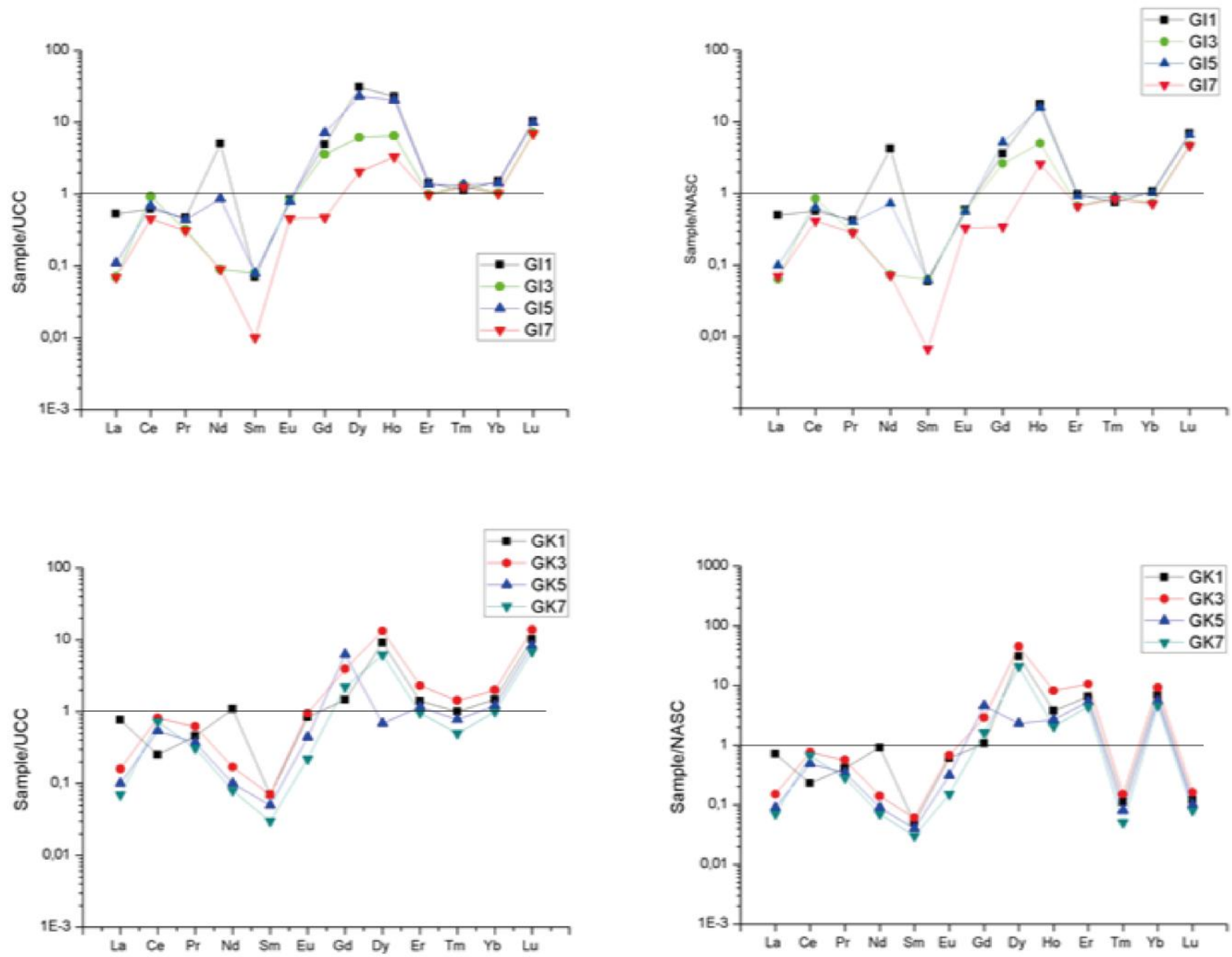

Figure 5 : REE distribution patterns of Triassic Oukaimeden sandstone from Ighermane station. REE data of UCC-normalization are from Taylorand MCLENNAN (1985) and NASC-normalization is from Haskin \& Haskin (1966). GK: AIT KEJOU sandstone; GI: IGHERMANE sandstone. 


\section{Weathering:-}

Sandstones from different tectonic setting have different geochemical characteristics (Bhatia, 1983; Roser and Korsch, 1986). The major element composition of clastic sedimentary rocks which have not been affected strongly by weathering process have a great value in the determination of their depositional environment (McLennan et al., 1993). However, some alkalis and alkaline earth elements (for example, $\mathrm{Ca}^{2+}, \mathrm{Na}^{+}$and $\mathrm{K}^{+}$) in terrigenous rocks can be sensitive to weathering conditions in the provenance (Wronkiewicz and Condie, 1987). Therefore, it is necessary to known the weathering degree of these rocks. The low to medium values of the chemical index of alteration (CIA) of these rocks indicate that they are not subject to several weathering, and thus will allow the use of these elements to differentiate between samples. The degree of chemical weathering is mainly linked to the climate and the rate of tectonic uplift (Wronkiewicz and Condie, 1987), the increase in the intensity of chemical weathering may reflect the decrease of the tectonic activity and/or the change in climate toward warm and wet conditions, which are more favorable for the chemical weathering of the source rocks (Jacobson et al., 2003). Consequently, the indices of alteration of the sedimentary rocks can provide useful information of the tectonic activity and the climatic conditions of the source area. The chemical index most commonly used in the quantification of alteration degree of the source rock is the chemical index alteration (CIA) (Nesbitt and Young, 1982). This index is defined by molecular proportions, where $\mathrm{CIA}=\left[\mathrm{Al}_{2} \mathrm{O}_{3} /\left(\mathrm{Al}_{2} \mathrm{O}_{3}+\mathrm{CaO}+\mathrm{Na}_{2} \mathrm{O}+\mathrm{K}_{2} \mathrm{O}\right)\right] \times 100$. For this study, CIA ranged from 56.86 to 84.05 in IGHERMANE sandstones samples, with an average of 71.77, suggesting a moderate weathering. In AIT KEJOU sandstones, CIA vary in a range of 47.27 to 71.18 , with an average of 57.60 suggesting that these sandstones have been submitted to a low alteration degree. These results suggest an abundance of igneous rocks fragments in our samples materialized by the low rates of alteration. In $\mathrm{Al}_{2} \mathrm{O}_{3}-\mathrm{CaO}+\mathrm{Na}_{2} \mathrm{O}-\mathrm{K}_{2} \mathrm{O}$ diagram (Fig.6), all IGHERMANE and AIT KEJOU sandstones samples fall above the line plagioclase-K-feldspar and biotite with a composition more near to the plagioclase than potassium feldspar and biotite. The majority of AIT KEJOU sandstones are located at some percentage of the feldspar seal which indicated the low quantity of alumina-bearing minerals (clay minerals), unlike IGHERMANE sandstones samples. This conclusion confirms the results obtained by the chemical index alteration (CIA).

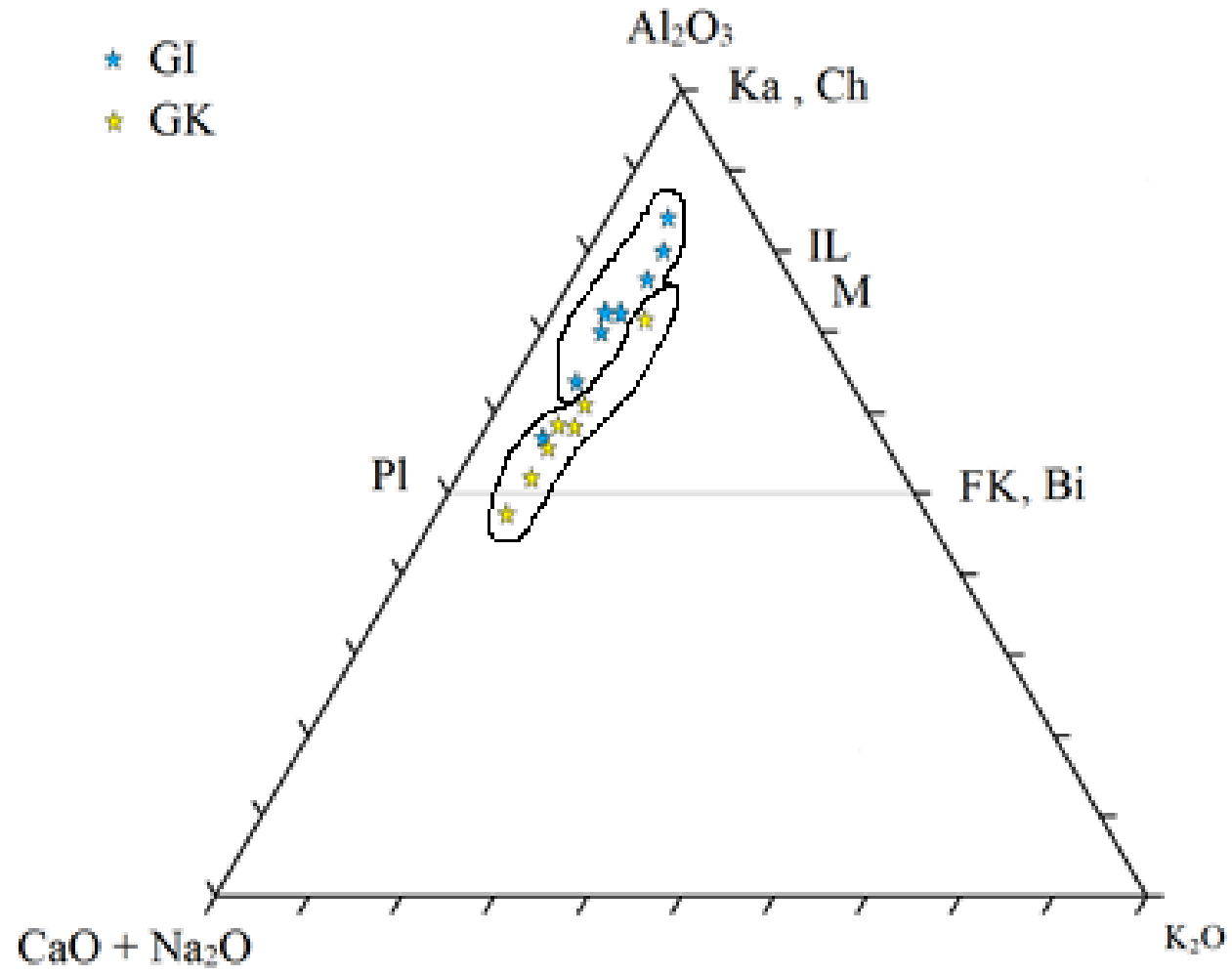

Figure 6: $\mathrm{Al}_{2} \mathrm{O}_{3^{-}} \mathrm{CaO}+\mathrm{Na}_{2} \mathrm{O}-\mathrm{K}_{2} \mathrm{O}$ ternary diagram (after Nesbitt and Young 1982) showing plots studied sandstones. GI: IGHERMANE sandstones, GK: AIT KEJOU sandstones, Ka: kaolinite, Ch : chlorite, Pl: plagioclase, IL: Ilite, M: muscovite, FK: potassium feldspar. 


\section{Provenance:-}

The provenance of these sedimentary rocks can be approached by $\mathrm{CaO}-\mathrm{Na}_{2} \mathrm{O}-\mathrm{K}_{2} \mathrm{O}$ triangular diagram (Bhatia,1983). According to a study conducted by Le Maitre (1976) on the chemical variability of 39 igneous rocks group, it proves that this diagram could indicate the provenance of our sandstones samples. Studied and analyzed sandstones samples fall into the field of andesites for AIT KEJOU sandstones and in the field of granite and granodiorite for IGHERMANE sandstones (Fig. 7). This result suggest that the provenance is constrained to the adjacent Cambrian basement units of Tifnout granitic massif, associated andesites(Baouch, 1984) and the granodiorites of the Precambrian basement units Central High Atlas(Proust, 1961), located to the south of the studied areas. These results confirmed those of major and rare earths elements geochemistry.

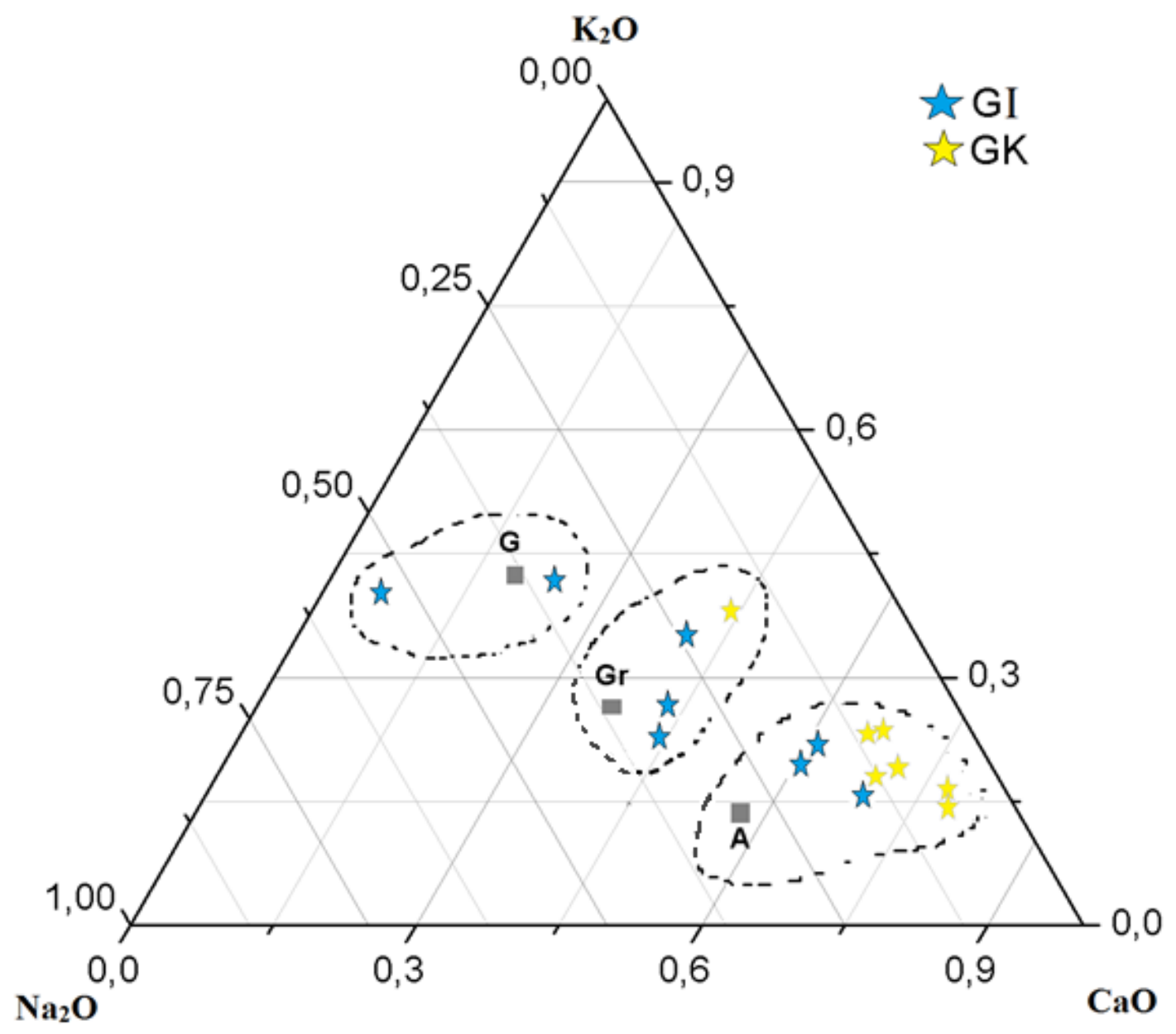

Figure 7: $\mathrm{CaO}-\mathrm{Na}_{2} \mathrm{O}-\mathrm{K}_{2} \mathrm{O}$ plot of Ighermane (GI) and AitKejou (GK) sandstone. G, GR and A are successively the average of granite, granodiorite and andesite after LeMaitre (1976).

\section{Tectonic setting:-}

Roser and Korsch (1986) defined three tectonic setting for terrigenous sedimentary rocks using the cross plot of $\mathrm{K}_{2} \mathrm{O} / \mathrm{Na}_{2} \mathrm{O}$ versus $\mathrm{SiO}_{2}$, as shown in Fig. 8A which indicates a passive margin for AIT KEJOU sandstones, except for GK2 and GK4 samples and an active continental margin tectonic setting for the IGHERMANE sandstones except for GI3 and GI4.

Bhatia (1983) defined four tectonic setting using the cross plot of $\mathrm{TiO}_{2}$ versus $\mathrm{Fe}_{2} \mathrm{O}_{3}+\mathrm{MgO}$, which are oceanic island arc, continental island arc, active continental margin, and the passive continental margin. Sandstones samples from IGHERMANE area plot in continental island arc and the active continental margin tectonic setting (Fig. 8B). However, AIT KEJOU sandstones samples plot in continental island arc and passive continental margin. Sandstones samples distribution in $\mathrm{TiO}_{2}$ versus $\mathrm{Fe}_{2} \mathrm{O}_{3}+\mathrm{MgO}$ (Fig 8B) suggests the presence of an orogenic signature. 

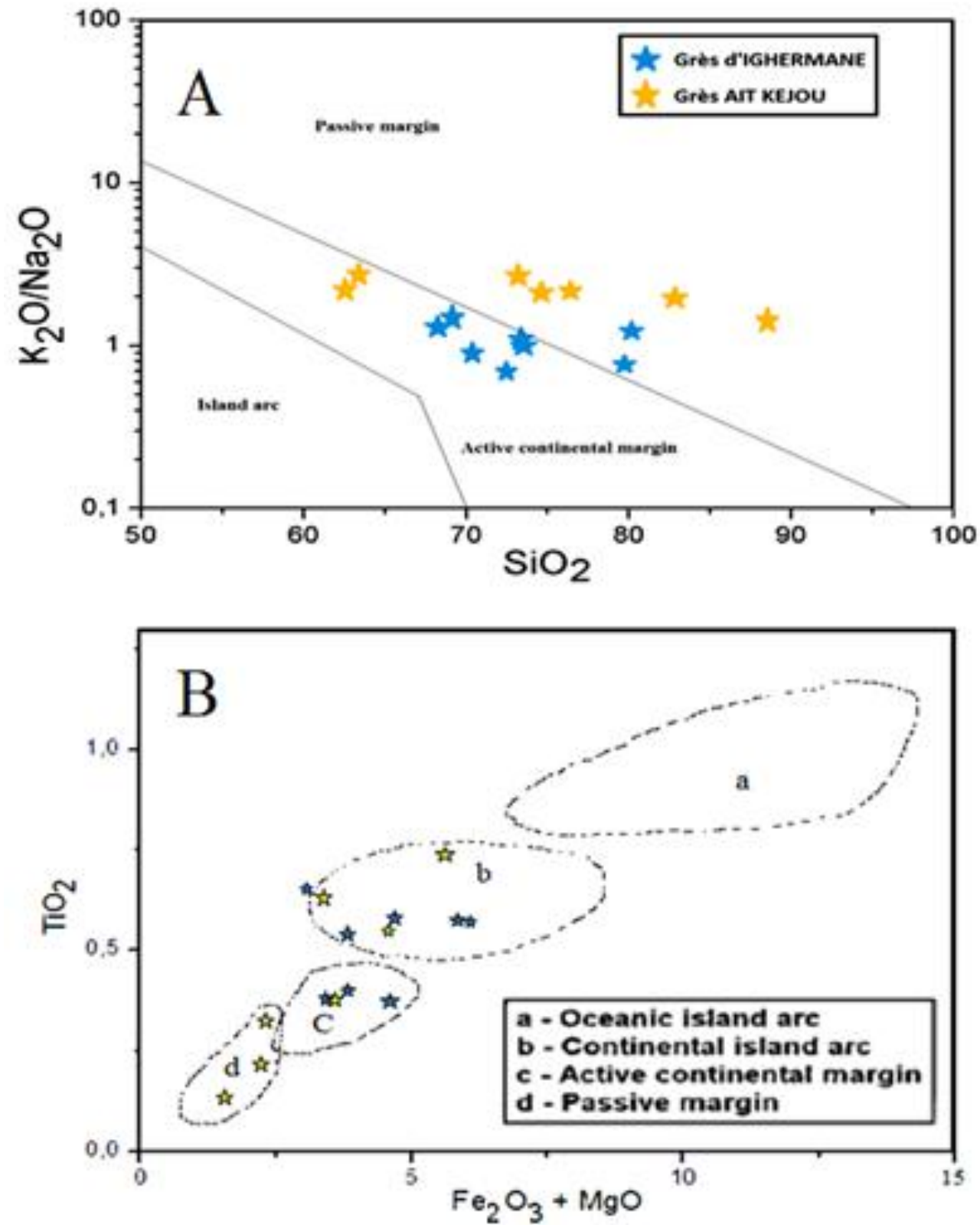

Figure 8 : Tectonic-setting discrimination diagrams of IGHERMANE and AIT KEJOU sandstones. The tectonic settings are named in each plot. A) $\mathrm{SiO}_{2}-\left(\mathrm{K}_{2} \mathrm{O} / \mathrm{Na}_{2} \mathrm{O}\right)$ After Roser and Korsch (1986); (B) $\mathrm{Fe}_{2} \mathrm{O}_{3}+\mathrm{MgO}-\mathrm{TiO}_{2}$ after Bhatia (1983).

\section{Conclusion:-}

A geochemical study has been carried out on Triassic sandstones from two areas of the Marrakech High Atlas, Morocco. The conclusion was to define their geochemical characterization, weathering, provenance and their tectonic setting. The results indicate that Oukaimeden sandstones are characterized by a high $\mathrm{SiO}_{2}$ content. According to Herron diagram, IGHERMANE sandstones are classified as wackes to litharenite whereas the AIT KEJOU sandstones are litharenites for the majority of samples. The low to medium $\mathrm{CIA}$ values and $\mathrm{Al}_{2} \mathrm{O}_{3}$ $\mathrm{Na}_{2} \mathrm{O}+\mathrm{CaO}-\mathrm{K}_{2} \mathrm{O}$ ternary diagram shows the presence of clay minerals in sandstones from the two studied areas, with a low amount suggesting the abundance of igneous rocks fragments in our sandstones samples. The positive correlation between $\mathrm{K} 2 \mathrm{O}$ and $\mathrm{Al}_{2} \mathrm{O}_{3}$ has a significant influence on the distribution of the aluminum and suggests that this element is mainly controlled by the amount of clay minerals. The negative linear relationship between $\mathrm{SiO}_{2}$ content and $\mathrm{TiO}_{2}, \mathrm{Al}_{2} \mathrm{O}_{3}, \mathrm{Fe}_{2} \mathrm{O}_{3}, \mathrm{MgO}$ and $\mathrm{K}_{2} \mathrm{O}$ content in the sandstones of the two areas suggest a mineralogical 
maturation with the presence of another $\mathrm{SiO}_{2}$ provenance. CIA values suggest low to moderate weathering in AIT KEJOU sandstones and moderate in IGHERMANE sandstones samples. The spectres patterns parallel appearances suggest that these sandstones have the same provenance. The negative europium $(\mathrm{Eu} / \mathrm{Eu} *)$ anomaly $(\mathrm{La} / \mathrm{Lu}) n, \mathrm{La} / \mathrm{Sc}$ ratios support a felsic provenance of the studied sandstones, except for GK1 and GK7 samples. Cerium (Ce/Ce*) anomaly suggest an oxidizing depositional environment. LREE/HREE and (La/Lu) ratios suggest a fluvial sedimentation with a slight sea contribution. Discrimination diagrams support passive margin tectonic setting for AIT KEJOU sandstones and an active margin tectonic setting for IGHERMANE sandstones. Sandstones samples distribution in $\mathrm{TiO}_{2}$ versus $\mathrm{Fe}_{2} \mathrm{O}_{3}+\mathrm{MgO}$ (Fig 8B) suggests the presence of an orogenic signature. The present study suggest that the provenance is constrained to the adjacent Cambrian basement units of Tifnout granitic massif, associated andesites (Baouch 1984) and the granodiorites of the Precambrian basement units Central High Atlas (Proust, 1961), located to the south of the studied areas.

\section{Acknowledgments:-}

This work is performed in the framework of the mixed research unit (UMR) between the National Center of Nuclear Energy Studies Sciences and Techniques (CNESTEN) and Hassan II University of Casablanca.

\section{References:-}

1. Anani. C., Chris Anani, Moradeyo. M., Atta-Peters.D., Kutu. J., Asiedu. D.,Boamah.D., 2013, Geochemistry and provenance of sandstones from Anyaboni and surrounding areas in the voltaian basin, Ghana: International Research Journal of Geology and Mining (IRJGM) (2276-6618) Vol. 3(6), pp. 206-212.

2. Baouch, S., 1984, Etude des ignimbrites et rochesassociées du massif de Tircht (Haut Atlas occidental, Maroc): contribution à l'étude des relations volcanisme-plutonisme du PIII = Ignimbrites and related rocks from the Tircht Massif (western High Atlas, Morocco): contribution to the study of the PIII volcanism-plutonism relations.

3. Baudon, C., Fabuel-Perez, I., and Redfern, J., 2009, Structural style and evolution of a Late Triassic rift basin in the Central High Atlas, Morocco: controls on sediment deposition: Geological Journal, v. 44, no. 6, p. 677-691, doi: 10.1002/gj.1195.

4. Benaouiss, N., Courel, L., and Beauchamp, J., 1996, Rift-controlled fluvial/tidal transitional series in the Oukai meden Sandstones, High Atlas of Marrakesh (Morocco): Sedimentary Geology, v. 107, no. 1-2, p. 2136, doi: 10.1016/S0037-0738(96)00013-9.

5. Bhatia, M.R., 1983, Plate Tectonics and Geochemical Composition of Sandstones: The Journal of Geology, v. 91, no. 6, p. 611-627.

6. Biron, P.-E., 1982, Le Permo-Trias de la région de l'Ourika (Haut-Atlas de Marrakech, Maroc): lithostratigraphie, sédimentologie, tectonique et minéralisations. [Theses]: UniversitéScientifiqueetMédicale de Grenoble.

7. Biron, P., and Courtinat, B., 1982, Contribution palynologique à la connaissance du Triasdu Haut-Atlas de Marrakech, Maroc: Geobios, v. 15, no. 2, p. 231-235, doi: 10.1016/S0016-6995(82)80023-5.

8. Cullers, R.L., 2000, The geochemistry of shales, siltstones and sandstones of Pennsylvanian-Permian age, Colorado, USA: implications for provenance and metamorphic studies: Lithos, v. 51, no. 3, p. 181-203, doi: 10.1016/S0024-4937(99)00063-8.

9. Dutuit, JM., 1976, Découverte d'amphibiens lepospondyles dans la série inférieure de la Formation rouge d'Argana (Atlas occidental marocain): Comptes Rendus de l'Academie des Sciences, Paris 283: 1733-1734.

10. Fabuel-Perez, I., Hodgetts, D., and Redfern, J., 2010, Integration of digital outcrop models (DOMs) and high resolution sedimentology - workflow and implications for geological modelling: Oukaimeden Sandstone Formation, High Atlas (Morocco): Petroleum Geoscience, v. 16, no. 2, p. 133-154, doi: 10.1144/1354-079309820 .

11. Haskin, M.A., and Haskin, L.A., 1966, Rare Earths in European Shales: A Redetermination: Science, v. 154, no. 3748, p. 507-509, doi: 10.1126/science.154.3748.507.

12. Houten, F.B.V., 1977, Triassic-Liassic Deposits of Morocco and Eastern North America: Comparison: AAPG Bulletin, v. 61, no. 1, p. 79-99.

13. Jacobson, A.D., Blum, J.D., Chamberlain, C.P., Craw, D., and Koons, P.O., 2003, Climatic and tectonic controls on chemical weathering in the New Zealand Southern Alps: Geochimica et CosmochimicaActa, v. 67, no. 1, p. 29-46, doi: 10.1016/S0016-7037(02)01053-0.

14. Jalil, N.E., Janvier, P., 2005, Les Pareiasaures (Amniota, Parareptilia) du Permien suprieur du Bassin d'Argana, Maroc:Geodiversitas 27: 35-132. 
15. Kayser, N.M., 2005, Sedimentology and sediment distribution of upper Triassic fluvio-aeolian reservoirs on a regional scale (Central Algeria, SW Morocco, NE Canada) [Ph.D.]: University of Manchester.

16. Manspeizer, W., 2015, Triassic-Jurassic Rifting: Continental Breakup and the Origin of the Atlantic Ocean and Passive Margins: Elsevier.

17. Mattis, A.F., 1977, Nonmarine Triassic Sedimentation, Central High Atlas Mountains, Morocco: Journal of Sedimentary Research, v. 47, no. 1.

18. McDaniel, D.K., Hemming, S.R., McLennan, S.M., and Hanson, G.N., 1994, Resetting of neodymium isotopes and redistribution of REEs during sedimentary processes: The Early Proterozoic Chelmsford Formation, Sudbury Basin, Ontario, Canada: Geochimica et CosmochimicaActa, v. 58, no. 2, p. 931-941, doi: 10.1016/0016-7037(94)90516-9.

19. McLennan, S.M., Hemming, S., McDaniel, D.K., and Hanson, G.N., 1993, Geochemical approaches to sedimentation, provenance, and tectonics: Geological Society of America Special Papers, v. 284, p. 21-40, doi: 10.1130/SPE284-p21.

20. Nesbitt, H.W., and Young, G.M., 1982, Early Proterozoic climates and plate motions inferred from major element chemistry of lutites: Nature, v. 299, no. 5885, p. 715-717, doi: 10.1038/299715a0.

21. Osman, M., 1996, Recent to Quaternary River Nile Sediments: A sedimentological characterization on samples from Aswan to Naga-Hammadi, Egypt:Unpub.Ph.D.thesis, Univ. of Vienna, Vienna, 162 pp.

22. Petit, J.-P., and Beauchamp, J., 1986, Synsedimentary faulting and palaeocurrent patterns in the Triassic sandstones of the High Atlas (Morocco): Sedimentology, v. 33, no. 6, p. 817-829, doi: 10.1111/j.13653091.1986.tb00984.x.

23. Proust, F., 1961, Etude stratigraphique, pétrographique et structurale du bloc oriental du Massif ancien du HautAtlas (Maroc):

24. Roser, B.P., and Korsch, R.J., 1986, Determination of Tectonic Setting of Sandstone-Mudstone Suites Using $\mathrm{SiO} 2$ Content and K2O/Na2O Ratio: The Journal of Geology, v. 94, no. 5, p. 635-650.

25. Roser, B.P., and Korsch, R.J., 1988, Provenance signatures of sandstone-mudstone suites determined using discriminant function analysis of major-element data: Chemical Geology, v. 67, no. 1, p. 119-139, doi: 10.1016/0009-2541(88)90010-1.

26. Rousseau, T.C.C., Sonke, J.E., Chmeleff, J., Candaudap, F., Lacan, F., Boaventura, G., Seyler, P., and Jeandel, C., 2013, Rare earth element analysis in natural waters by multiple isotope dilution - sector field ICP-MS: Journal of Analytical Atomic Spectrometry, v. 28, no. 4, p. 573-584, doi: 10.1039/C3JA30332B.

27. Taj-Eddine, K., Pignone, R., 2005, L’Ourika: Haut Atlas-Haouz de Marrakech, Maroc: In SELCA (ed.): Un patrimoine geologique, biologique et culturel exceptionnel. Florence, Italy (scale 1:60 000, 1 sheet).

28. Taylor, S.R., and McLennan, S.M., 1985, The continental crust: Its composition and evolution:

29. Wronkiewicz, D.J., and Condie, K.C., 1987, Geochemistry of Archeanshales from the Witwatersrand Supergroup, South Africa: Source-area weathering and provenance: GeochimicaetCosmochimicaActa, v. 51, no. 9, p. 2401-2416, doi: 10.1016/0016-7037(87)90293-6. 